\title{
Chromium Stress Tolerance of a C4 (Zea mays L.) and C3 (Vigna radiata L.) Plants Primed with UV and Gamma-Treated Bacillus subtilis
}

\author{
Qasim Shahzad ${ }^{1}$, Saqib Mahmood ${ }^{2}$, Sadia Javed ${ }^{1, *}$ and Tariq Mushtaq ${ }^{3}$ \\ 1 Department of Biochemistry, Government College University, Faisalabad 38000, Pakistan; \\ qasimkainth60@gmail.com \\ 2 Department of Botany, Government College University, Faisalabad 38000, Pakistan; drsaqibj@gmail.com \\ 3 Agrovision, Faisalabad 38000, Pakistan; tariq@agrovisions.com \\ * Correspondence: sadiajaved@gcuf.edu.pk
}

Citation: Shahzad, Q.; Mahmood, S.; Javed, S.; Mushtaq, T. Chromium Stress Tolerance of a C4 (Zea mays L.) and C3 (Vigna radiata L.) Plants Primed with UV and Gamma-Treated Bacillus subtilis. Microorganisms 2021, 9, 2313. https:// doi.org/10.3390/microorganisms 9112313

Academic Editor: José David Flores-Félix

Received: 28 September 2021

Accepted: 28 October 2021

Published: 8 November 2021

Publisher's Note: MDPI stays neutral with regard to jurisdictional claims in published maps and institutional affiliations.

Copyright: () 2021 by the authors. Licensee MDPI, Basel, Switzerland. This article is an open access article distributed under the terms and conditions of the Creative Commons Attribution (CC BY) license (https:// creativecommons.org/licenses/by/ $4.0 /)$.

\begin{abstract}
Chromium stress is one of the deleterious abiotic factors that reduce crop production. Two anatomically different crops (C3 and C4) were compared for their chromium (0 and $50 \mathrm{ppm})$ tolerance and responses towards Bacillus subtilis (B. subtilis). Strains of B. subtilis were exposed to UV (30-210 $\mathrm{min}$ ) and gamma irradiation (1-4 KGy), and the best mutants were selected on petri plates containing selective markers. Maize and mungbean were supplied with selected strains or the parent strain in rooting medium, along with a nutrient broth. A completely randomized design (five replicates) was adopted using nutrient broth as a control. Stress negatively affected plants grown without strains. Mungbean was more sensitive towards stress and treatments, maize had better root and shoot fresh weights, root and shoot lengths, proline levels, and MDA and GR activity. All strains of B. subtilis (parent, $\gamma$-irradiated and UV-irradiated) enhanced proline, total soluble protein, chlorophyll $\mathrm{a}, \mathrm{a}+\mathrm{b}$ and $\mathrm{a} / \mathrm{b}$ levels, with negligible effects upon antioxidant enzymes. Irradiated strains proved their superiority to the parent strain, with reductions in $\mathrm{H}_{2} \mathrm{O}_{2}$ and MDA content. With comparable benefits, $\gamma$ and UV irradiation may be adopted in future based upon technical availability.
\end{abstract}

Keywords: Bacillus subtilis; proline; chlorophyll; osmolyte; antioxidative enzymes; maize; mung bean

\section{Introduction}

Heavy metals are present in the vast majority of biotic and abiotic matter and frequently enter into the food chain. As a result of plant uptake, they negatively affect crop yield and food quality [1]. One of major reasons behind its spread is the rapid industrialization and use of contaminated waste water for irrigation without proper treatment [2]. Chromium is a heavy metal that negatively affects flora and fauna around the globe. It is found in a vast range of reservoirs including soil, ground water, and sediments. [3]. Plants growing under chromium stress uptake Cr (IV), which unavoidably changes plant morphology and physiology [4-6]. Absorbed $\mathrm{Cr}$ is not only located in roots but also translocates to the above-ground plant parts [7]. Therefore, it has opportunities to toxify whole-plant metabolism [8]. Chromium toxicity in plants causes reductions in growth and pigment content, as well as altered enzymatic activities [9-11].

Stressed plants experience over-accumulation of reactive oxygen species (ROS) such as superoxide, peroxides, hydroxyl radicals and singlet oxygen. Excessive production of these species during photorespiration may destroy cell organelles. In addition, they can lead to cell death with enzymatic inhibition and oxidation of nucleic acids, lipids and proteins [12]. Plants produce enzymatic and non-enzymatic antioxidants to counteract ROS and resist/tolerate stressed conditions. Non-enzymatic antioxidants include ascorbic acid, $\beta$-carotene and tocopherols. Among the enzymatic antioxidants, catalase (CAT), peroxidase (POD), ascorbate peroxidase (APX) and superoxide dismutase (SOD) are the 
most commonly reported enzymes with antioxidant capacity (Figure 1). Another strategic solution that plants use for fighting against stresses is the accumulation of osmolytes such as soluble sugars, glycine, betaine, proline and proteins. These compatible osmolytes stabilize the cell molecular structure [13,14].

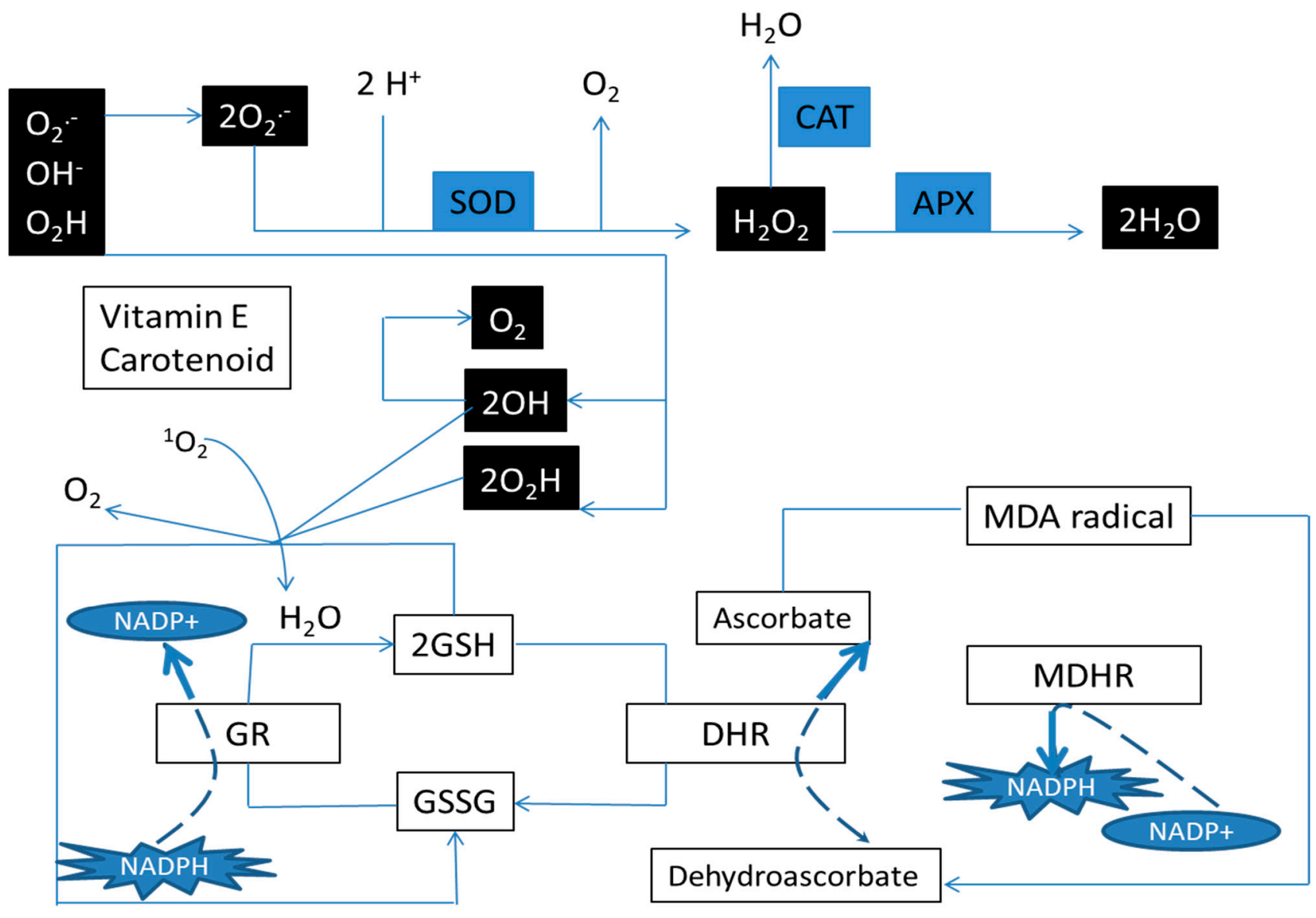

Figure 1. Enzymatic and non-enzymatic antioxidant system in plants. Enzymatic: Superoxide dismutase (SOD), catalase (CAT), ascorbate peroxidase (APX), Non-Enzymatic: oxidized glutathione (GSH), reduced (GSSG), monodehydroascorbate reductase (MDHR), dehydroascorbate reductase (DHR) and glutathione reductase (GR).

In case of longer exposure to stress or excessive contamination, natural neutralization of these ROS by antioxidant and osmolytes is not sufficient to alleviate the phytotoxicity of heavy metals in plants [15-17]. Plants need additional strategies to cope with such issues.

One possible economic and ecofriendly solution is the use of microbial communities, such as mycorrhizal fungi and plant growth-promoting bacteria (PGPB). Microbes known for their positive role in plant growth and development are being searched for their potential to support plants against abiotic and biotic stresses. To date, a number of microbes have been reported to promote the growth and development of normal and stressed plants; Bacillus is one of those [18-21].

Plants with differing structures and functions also vary in their adaptation to climatic conditions [22,23]. Based upon their anatomical differences, plants are generally categorized as C3/C4, where C3 plants have a distinctive leaf anatomy with a well-defined bundle sheath, chloroplast dimorphism, two carboxylation pathways in the bundle sheath cells and limited photorespiration. Generally, C3 plants are believed to have a temperate origin, while C4 plants have evolved in tropical and arid environments. While considering plant responses to their environmental conditions, anatomical and physiological distinctions may affect their adaption strategies [22]. 
After heavy metal uptake, in comparison to C4 plants, C3 species with higher biomass under elevated atmospheric carbon dioxide show a better potential for removing environmental contaminants [23]. Microbial association is reported to additionally favor tolerance strategies for elevated $\mathrm{CO}_{2}$.

Maize (a C4 plant) and Mung bean (a C3 plant) are two important food crops. Maize is rich in essential amino acids, act as a gluten-free diet food, fortifies bones and boosts the nervous system. Mung bean (Vigna radiata L.) is an important small cash legume crop of Asia. With a good content of protein (21-24\%), mung bean plants play and important role as food, fodder and green manure for soil improvement [24,25]. Better and enhanced yields of both crops may be improved by improving stress tolerance for better utilization of contaminated areas. Keeping in view the nutritive value of maize $(C 4)$ and mung bean (C3), chromium as a major constraint for plant growth and metabolism, and B. subtilis as a potential plant growth promoter, the present study was planned. Additionally, it was aimed to improve the $B$. subtilis strain by exposing it to UV and $\gamma$-irradiation. The major objective was to determine the more resistant/stress-tolerant strain and to determine the extent to which it can improve the growth and metabolism of a C4 (maize) and C3 (mung bean) species.

\section{Materials and Methods}

\subsection{Mutagenic Treatments and Selection of Mutants}

The Bacillus subtilis (accession no. MW356848) strain used in this study was isolated by our research laboratory. This $B$. subtilis strain was inoculated in nutrient broth medium and exposed to UV (30,60, 90, 120, 150, 180 and $210 \mathrm{~min})$ at a single dose, lambda 360 for various time intervals and gamma radiations $(1,2,3$ and $4 \mathrm{kGy})$ at different dose rates for a fixed time interval. For UV mutation, the spores of $B$. subtilis $\left(1 \times 10^{7}\right.$ spores $\left./ \mathrm{mL}\right)$ were exposed to UV irradiation by using a UV lamp (Phillips, $20 \mathrm{~W}, \lambda 360$, distance of the lamp from the petri plates was $20 \mathrm{~cm}$ ). The samples $(1 \mathrm{~mL}$ ) were withdrawn after 30 min until $240 \mathrm{~min}$ [26]. For Gamma mutation, four test tubes, each having $1 \mathrm{ml}$ of spore suspension, were irradiated with $\gamma$-rays in a Cz137 source at different ranges of $1-4 \operatorname{KGy}(1,2,3,4)$. The irradiated spores after both treatments were diluted serially with nutrient broth medium and then an appropriate volume was spread on nutrient agar plates containing $0.2 \%$ triton $\mathrm{X}-100$ as a colony restrictor. After overnight incubation at $37^{\circ} \mathrm{C}$, the colony-forming units were counted at a dilution giving rise to 100-200 colonies per plate, to determine the kill survival percentage. The irradiated spores were selected on agar plates containing 2-deoxy D-glucose (antimetabolite), used as a selective marker. The suppression/inhibition of the glycolysis process deprived the sensitive cells of ATP — the surviving strains, proving their resistance/stress tolerance, were counted on the plates and selected as the study mutants.

\subsection{Minimum Inhibitory Concentration}

The tolerance of each isolate was assessed for $\mathrm{Cr}$ stress with minimal inhibitory concentrations (MICs). For this purpose, different $\mathrm{Cr}$ concentrations (0 to $1500 \mathrm{mg} / \mathrm{L}$ potassium dichromate) were used. The highest $\mathrm{Cr}$ concentration at which no growth was observed on $\mathrm{Cr}$-containing nutrient-agar media was considered as the MIC.

\subsection{Field Experiment}

For field experiments, maize (Mallika) and mung bean (PRI-2018) seeds were obtained from Ayyub Agricultural Institute Faisalabad. Completely randomized experiments were designed with four replicates using plastic pots of $25 \mathrm{~cm}$ in depth and $12 \mathrm{~cm}$ in radius. Each pot was filled with $5 \mathrm{~kg}$ of clay-loam soil. In each pot, six seeds were sown. One week after sowing, the germinated seedlings were thinned to maintain five plants in each pot. The soil moisture content was maintained daily. Three weeks after germination, two chromium levels $(0 \mathrm{ppm}$ and $50 \mathrm{ppm})$ were maintained using potassium dichromate. After two weeks of chromium application, all the experimental units were subjected to root supplementations. Nutrient broth (13 g of oxoid nutrient broth powder (CM0001B) 
dissolved in $1 \mathrm{~L}$ of distilled water) was used to prepare the fungal supplements. Hence, plants exclusively supplemented with nutrient broth were considered as controls. This control was used as a comparison for the growth and biochemical attributes of maize and mung bean with three B. subtilis applications (parent, UV-irradiated and $\gamma$-irradiated strains in nutrient broth). After two weeks of application, harvests were taken to collect data on growth and biochemical attributes. Growth attributes included root and shoot length, and shoot fresh and dry weights. Biochemical attributes were determined as follows.

\subsection{Antioxidant Enzymes}

Catalase activity was estimated following Cakmak \& Horst [27]. For the determination of total protein, the extract was prepared by homogenizing $0.5 \mathrm{~g}$ of frozen leaf material in $0.05 \mathrm{M}$ Tris- $\mathrm{HCl}$ buffer (pH 7). It was centrifuged in $4{ }^{\circ} \mathrm{C}$ for $30 \mathrm{~min}$ at $13,000 \mathrm{rpm} / \mathrm{min}$. For catalase activity, $500 \mu \mathrm{L}$ of $10 \mathrm{mM} \mathrm{H}_{2} \mathrm{O}_{2}$, sodium phosphate buffer $(1400 \mu \mathrm{L}$ of $25 \mathrm{mM})$ and $100 \mu \mathrm{L}$ of crude enzyme extract were used. Decreases in absorbance were recorded at $240 \mathrm{~nm}$ for $1 \mathrm{~min}$. Ascorbate oxidase activity was determined using the method of Wang et al. [28]. For peroxidase, $\mathrm{H}_{2} \mathrm{O}_{2}(500 \mu \mathrm{L}$ of $5 \mathrm{~mm})$, guaiacol $(500 \mu \mathrm{L}$ of $28 \mathrm{mM})$, and potassium phosphate buffer $(1900 \mu \mathrm{L}$ of $60 \mathrm{mM}$ with $\mathrm{pH}$ 6.1) was used as the substrate and $100 \mu \mathrm{L}$ crude extract was taken as the enzyme source. Differences in absorbance were recorded at $470 \mathrm{~nm}$ for $1 \mathrm{~min}$ with a spectrophotometer [29]. Leaf tissue $(0.1 \mathrm{~g})$ was ground in liquid nitrogen and then homogenized in $0.4 \mathrm{~mL}$ of phosphate buffer $(50 \mathrm{mM}$ at $\mathrm{pH} 7.0)$, ascorbic acid $(1 \mathrm{mM})$, polyvinylpoly pyrrolidone $(2 \%)$, triton $(0.05 \%)$ and $1 \mathrm{mM}$ ethylene diamine tetraacetic acid (EDTA). The mixture was centrifuged at $17,000 \times g$ for $20 \mathrm{~min}$, and the supernatant containing $0.5 \mathrm{mM}$ oxidized glutathione, $0.1 \mathrm{M}$ Tris buffer ( $\mathrm{pH} 7.8), 50 \mu \mathrm{M}$ $\mathrm{NADPH}, 2 \mathrm{mM}$ EDTA, and $20 \mu \mathrm{L}$ of the extract was taken for further investigation. The assay was initiated by the addition of NADPH for $5 \mathrm{~min}$ at $25^{\circ} \mathrm{C}$. The oxidation reaction for measuring GR activity was followed by monitoring the absorbance at $340 \mathrm{~nm}$ using a UV-Vis spectrophotometer [30].

\subsection{Lipid Peroxidation}

For estimation of malondialdehyde (MDA), plant samples were homogenized in $3 \mathrm{~mL}$ of 0.1 trichloroacetic acid. The crude extract was mixed with the same volume of a $0.5 \%(w / v)$ tribarbitoric acid solution containing $20 \%(w / v)$ trichloroacetic acid. This was followed by $30 \mathrm{~min}$ heating and then rapid cooling. The absorbance of the supernatant was measured at $530 \mathrm{~nm}$. Plant samples (frozen in liquid nitrogen and stored at $80^{\circ} \mathrm{C}$ ) were ground and $100 \mathrm{mg}$ of the powder was homogenized with $5 \mathrm{~mL}$ of the solution containing $0.25 \mathrm{~mL}$ trichloroacetic acid $(0.1 \%, 1 \mathrm{~mL} \mathrm{KI}(1 \mathrm{M})$ and $0.5 \mathrm{~mL}$ potassium phosphate buffer $(10 \mathrm{mM})$ The homogenate was centrifuged at $12,000 \times \mathrm{g}$ for $15 \mathrm{~min}$ at $4{ }^{\circ} \mathrm{C}$. The supernatant $(500 \mu \mathrm{L})$ from each tube was kept at room temperature (about $25^{\circ} \mathrm{C}$ ) for $15 \mathrm{~min}$ [31].

\subsection{Osmolyte and Protein Content}

Fresh harvested leaf samples were frozen to $0{ }^{\circ} \mathrm{C}$ and then frozen to $-40{ }^{\circ} \mathrm{C}$. For sugar extraction, $0.1 \mathrm{~g}$ samples were chopped and added to $10 \mathrm{~mL}$ of $80 \%$ ethanol $(v / v)$, followed by overnight shaking. Proline content was estimated by the method shown in [32]. Leaf samples $(0.5 \mathrm{~g})$ were homogenized in aqueous sulfosalicylic acid ( $3 \%)$, followed by centrifugation at $4{ }^{\circ} \mathrm{C}$ for $10 \mathrm{~min}$ at $10,000 \mathrm{rpm} / \mathrm{min}$. The resultant supernatant of $1 \mathrm{~mL}$, along with $1 \mathrm{~mL}$ acid ninhydrin and $1 \mathrm{~mL}$ of glacial acetic acid, was incubated at $100{ }^{\circ} \mathrm{C}$ for $1 \mathrm{~h}$. The reaction mixture was extracted with $4 \mathrm{~mL}$ toluene on ice and the absorbance was noted at $520 \mathrm{~nm}$. Soluble proteins were estimated from fresh leaves extracted with phosphate buffer solution ( $\mathrm{pH} 7$ ). From the filtrate, total protein was estimated using the method of Lowery et al. [33].

\subsection{Photosynthetic Pigments}

The chlorophyll content was determined following the method reported by Ptala [34]. For carotenoids, the estimation method of Davis [35] was adopted. 


\subsection{Statistical Analysis}

A two-way analysis of variance (ANOVA) of data for all attributes was carried out using CoStat a CoHort 6.4 for each crop independently. Mean values were compared using LSD.

\section{Results}

A total of eleven bacterial strains-seven from UV and four from $\gamma$-irradiation treatment-were grown on petri plates containing nutrient agar medium along with 2-deoxy D-glucose as a selective marker, and only BSU-5, BSU-7 and BS $\gamma-4$ were found to be grown on petri plates (Table 1). All strains were also tested for their minimum inhibition concentration. Overall, BSU-7 and BS $\gamma-4$ was able to tolerate $\mathrm{K}_{2} \mathrm{Cr}_{2} \mathrm{O}_{7}$ up to $180 \mathrm{ppm}$ in the culture media, whereas most of the remaining isolates were found to be tolerant to this salt up to $60 \mathrm{ppm}$, except for isolate BSU-5, which tolerated $90 \mathrm{ppm} \mathrm{K}_{2} \mathrm{Cr}_{2} \mathrm{O}_{7}$ (Table 2).

Table 1. Selection of best mutants on the selective marker.

\begin{tabular}{ll}
\hline Strains & Growth on Selective Marker \\
\hline BSU-1 & -ve \\
BSU-2 & -ve \\
BSU-3 & -ve \\
BSU-4 & + ve \\
BSU-5 & -ve \\
BSU-6 & -ve \\
BSU-7 & + ve \\
BS $\gamma-1$ & -ve \\
BS $\gamma-2$ & -ve \\
BS $\gamma-3$ & -ve \\
BS $\gamma-4$ & + ve \\
\hline
\end{tabular}

+ve $=$ growth was observed on Petri plates, - ve $=$ no growth was observed on Petri plates.

Table 2. Minimum inhibitory concentration of isolates for $\mathrm{Cr}$ stress concentrations.

\begin{tabular}{|c|c|c|c|c|c|c|c|c|}
\hline \multirow[t]{2}{*}{ Strains } & \multicolumn{8}{|c|}{ Cr Concentration (ppm) } \\
\hline & 0 & 30 & 60 & 90 & 120 & 150 & 180 & 210 \\
\hline BSU-1 & +ve & +ve & -ve & -ve & -ve & -ve & -ve & -ve \\
\hline BSU-2 & +ve & +ve & +ve & -ve & -ve & -ve & -ve & -ve \\
\hline BSU-3 & +ve & +ve & -ve & -ve & -ve & -ve & -ve & -ve \\
\hline BSU-4 & +ve & +ve & +ve & -ve & -ve & -ve & -ve & -ve \\
\hline BSU-5 & +ve & +ve & -ve & +ve & -ve & -ve & -ve & -ve \\
\hline BSU-6 & +ve & +ve & -ve & -ve & -ve & -ve & -ve & -ve \\
\hline BSU-7 & +ve & +ve & +ve & +ve & +ve & +ve & +ve & -ve \\
\hline $\mathrm{BS} \gamma-1$ & +ve & +ve & +ve & -ve & -ve & -ve & -ve & -ve \\
\hline $\mathrm{BS} \gamma-2$ & +ve & +ve & -ve & -ve & -ve & -ve & -ve & -ve \\
\hline $\mathrm{BS} \gamma-3$ & +ve & +ve & -ve & -ve & -ve & -ve & -ve & -ve \\
\hline $\mathrm{BS} \gamma-4$ & +ve & +ve & +ve & +ve & +ve & +ve & +ve & -ve \\
\hline
\end{tabular}

+ve $=$ growth was observed on Petri plates, -ve $=$ no growth was observed on Petri plates.

In the current study, out of eleven different strains, seven were exposed to UV irradiation (30-210) and four were exposed to $\gamma$-irradiation (1-4 kGy). The selection criteria for B. subtilis strains out of the seven UV and four $\gamma$-treatments was superiority in Cr-tolerance and growth on the selective marker. Among the isolated strains, two B. subtilis strains BSU-7 and BS $\gamma-4$ were selected (Tables 1 and 2).

Data on the morphological attributes of maize and mung bean was subjected to analysis of variance. Results showed high significance $(p \leq 0.001)$ for stress, treatments and their interactions for shoot and root fresh and dry weight, and shoot and root lengths for maize and mung bean (Tables 3 and 4; Figure 2A-D). Exogenously applied (UV and $\gamma$-irradiated) B. subtilis significantly improved shoot biomass exclusively in stressed mung 
bean, whereas for root weights (fresh and dry), with the exception of maize growing under $0 \mathrm{ppm}$ stress, all plants experienced enhanced values of these attributes in nutrient medium supplemented with $B$. subtilis, as compared to the plants grown in nutrient medium without any strain. With regards to the lowering of root fresh and dry weights with stress (50 ppm), both crops experienced its reduction. Bacterial applications were more effective in mung bean, with marked improvement of these attributes. There was a marked suppression of shoot length in maize, but significant increase in the root length of both with the chromium stress (Figure 2E,F). B. subtilis improved the shoot as well as the root lengths of both stressed crops. The best lengths were displayed by the $\gamma$-irradiated plants, followed by the UV and Parent strains.

Table 3. Mean Squares from two way analysis of variance data for different morphological and biochemical indicators of Maize (Zea mays L.) treated with Bacillus subtilis under chromium stress.

\begin{tabular}{|c|c|c|c|c|c|c|}
\hline Source of Variation & df & Shoot FW & Shoot DW & Root FW & Root DW & Shoot Length \\
\hline Stress (S) & 2 & $0.9325^{* * *}$ & $0.1386^{* * *}$ & $0.0902 * * *$ & $0.0856^{* * *}$ & $0.680 * * *$ \\
\hline Treatment $(\mathrm{T})$ & 3 & $113.212^{* * *}$ & $1.282^{* * *}$ & $29.10^{* * *}$ & $1.064^{* * *}$ & $270.12^{* * *}$ \\
\hline \multirow[t]{2}{*}{$\mathrm{S} \times \mathrm{T}$} & 6 & $0.346^{* * *}$ & $0.720 * * *$ & $0.234^{* * *}$ & $0.0119^{* * *}$ & $0.3113^{* * *}$ \\
\hline & & Root Length & Proline & MDA & $\mathrm{H}_{2} \mathrm{O}_{2}$ & Protein \\
\hline Stress (S) & 2 & $0.285^{* * *}$ & $0.0077^{* * *}$ & $3.083^{* * *}$ & $0.0013^{* * *}$ & $2.586^{* * *}$ \\
\hline Treatment $(\mathrm{T})$ & 3 & $1150.88^{* * *}$ & $0.499 * * *$ & $0.3531^{* * *}$ & $0.3165^{* * *}$ & $0.105^{* * *}$ \\
\hline \multirow[t]{2}{*}{$\mathrm{S} \times \mathrm{T}$} & 6 & $0.547^{* * *}$ & $1.409^{\mathrm{ns}}$ & $0.0010^{* * *}$ & $1.57^{\mathrm{ns}}$ & $3.861^{\mathrm{ns}}$ \\
\hline & & Catalase & APX & GR & POD & SOD \\
\hline Stress (S) & 2 & $8.694^{\mathrm{ns}}$ & $2.194^{* * *}$ & $0.0017 *$ & $8.0833^{* * *}$ & $11.083^{* * *}$ \\
\hline Treatment (T) & 3 & $193,581.7^{* * *}$ & $67,589.06^{* * *}$ & $1078.4^{* * *}$ & $202,487.74^{* * *}$ & $98,622.4^{* * *}$ \\
\hline \multirow[t]{2}{*}{$\mathrm{S} \times \mathrm{T}$} & 6 & $15.95^{\mathrm{ns}}$ & $1.3425^{* * *}$ & $3.416^{\mathrm{ns}}$ & $0.0555^{* * *}$ & $0.0833^{\mathrm{ns}}$ \\
\hline & & Chl a & Chl $a+b$ & Car & Chla/b & \\
\hline Stress (S) & 2 & $0.0010^{\mathrm{ns}}$ & $2.612^{* * *}$ & $0.0016 * * *$ & $2.61^{* * *}$ & \\
\hline Treatment $(\mathrm{T})$ & 3 & $68.135^{* * *}$ & $7.59^{* * *}$ & $0.0120 * * *$ & $7.62^{* * *}$ & \\
\hline $\mathrm{S} \times \mathrm{T}$ & 6 & $0.0029^{n s}$ & $2.41^{* * *}$ & $0.0084^{* * *}$ & $2.391^{* * *}$ & \\
\hline
\end{tabular}

Table 4. Mean Squares from two way analysis of variance data for different morphological and biochemical indicators of Mung bean (Vigna radiata L.) treated with Bacillus subtilis under chromium stress.

\begin{tabular}{|c|c|c|c|c|c|c|}
\hline Source of Variation & df & Shoot FW & Shoot DW & Root FW & Root DW & Shoot Length \\
\hline Stress (S) & 2 & $9.284^{* * *}$ & $1.425^{* * *}$ & $0.0033^{* * *}$ & $0.0350 * * *$ & $0.0099 * * *$ \\
\hline Treatment $(\mathrm{T})$ & 3 & $0.0096^{* * *}$ & $2.469 * * *$ & $0.0029^{* * *}$ & $1.0230^{* * *}$ & $253.78^{* * *}$ \\
\hline \multirow[t]{2}{*}{$\mathrm{S} \times \mathrm{T}$} & 6 & $0.0011^{* * *}$ & $3.491^{* * *}$ & $0.0012^{* * *}$ & $0.0092^{* * *}$ & $0.1922 * * *$ \\
\hline & & Root Length & Proline & MDA & $\mathrm{H}_{2} \mathrm{O}_{2}$ & Protein \\
\hline Stress (S) & 2 & $0.4967 * * *$ & $0.0052 * * *$ & $2.860 * * *$ & $0.0015^{* * *}$ & $5.361^{* * *}$ \\
\hline Treatment (T) & 3 & $133.16^{* * *}$ & $1.1732 * * *$ & $1.281 * * *$ & $0.313^{* * *}$ & $0.141^{* * *}$ \\
\hline \multirow[t]{2}{*}{$\mathrm{S} \times \mathrm{T}$} & 6 & $0.2990^{* * *}$ & $1.111^{\mathrm{ns}}$ & $3.675 * * *$ & $1.38^{\mathrm{ns}}$ & $1.484^{\mathrm{ns}}$ \\
\hline & & Catalase & APX & GR & POD & SOD \\
\hline Stress (S) & 2 & $6.583 * * *$ & $3166.5^{* * *}$ & $7.583 * * *$ & $6.0277^{* * *}$ & $6.194^{* * *}$ \\
\hline Treatment (T) & 3 & $284,498.0^{* * *}$ & $8134.02 * * *$ & $1411.4^{* * *}$ & $178,010.19^{* * *}$ & $178,701.3^{* * *}$ \\
\hline \multirow[t]{2}{*}{$\mathrm{S} \times \mathrm{T}$} & 6 & $0.879 * * *$ & $25,551.1^{* * *}$ & $2.5^{\mathrm{ns}}$ & $9.435^{* * *}$ & $2.083^{* * *}$ \\
\hline & & Chl a & Chl $a+b$ & Car & Chl a/b & \\
\hline Stress (S) & 2 & $0.0015^{\mathrm{ns}}$ & $2.6^{* * *}$ & $6.194^{* *}$ & $2.61^{* * *}$ & \\
\hline Treatment $(\mathrm{T})$ & 3 & $60.102^{* * *}$ & $7.63^{* * *}$ & $0.0350^{* * *}$ & $7.62 * * *$ & \\
\hline $\mathrm{S} \times \mathrm{T}$ & 6 & $2.0833^{\mathrm{ns}}$ & $2.4^{* * *}$ & $0.0025^{* * *}$ & $2.391^{* * *}$ & \\
\hline
\end{tabular}



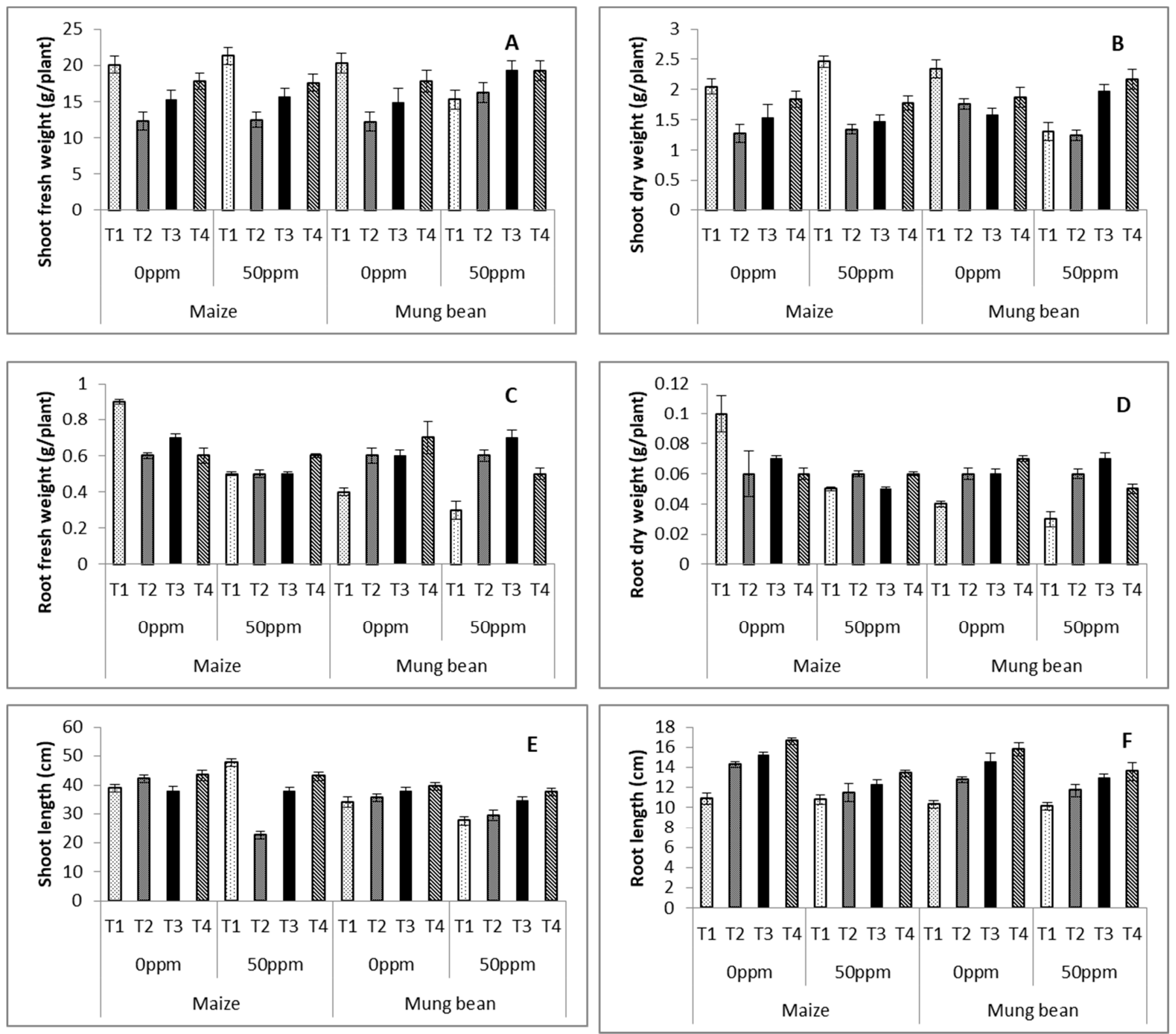

Figure 2. Shoot fresh (A) and dry (B) weights, root fresh (C) and dry (D) weights, shoot (E) and root (F) lengths, of maize (Zea mays L.) and mung bean (Vigna radiata L.) exogenously treated with $B$. subtilis under chromium stress conditions (mean \pm S.E.). Here, T1 = Nutrient broth, $\mathrm{T} 2=$ Nutrient broth + parent $B$. subtilis, $\mathrm{T} 3=$ Nutrient broth $+\mathrm{UV}$ irradiated B. subtilis and $\mathrm{T} 4=$ Nutrient broth $+\gamma$-irradiated $B$. subtilis.

Statistical analysis of enzymatic activities showed significance for the majority of parameters $(p \leq 0.001)$, along with significant interactions (Tables 3 and 4). The activity of CAT was reduced in maize with chromium stress $(50 \mathrm{ppm})$. Parent $B$. subtilis improved this attribute unanimously for both chromium levels in each crop. UV and $\gamma$-irradiated strains exclusively increased CAT activity in stressed maize.

There was a negligible effect of stress upon SOD activity in control plants (nutrient broth without any strain). None of the strains were successful in improving its activity in comparison to the nutrient supplement without microbes (T1).

The activity of POD was better displayed by mung bean in comparison to maize at both chromium levels. The response of $B$. subtilis strains was poorer than in the control (nutrient medium without strains), as with SOD. 
APX enzymatic activity increased significantly $(p \leq 0.001)$ in mung bean with the increase of chromium levels (50 ppm). In maize, there was marked improvement in APX activity in plants supplemented with B. subtilis strains. In mung bean, only the parent $B$. subtilis has positive effects at $0 \mathrm{ppm}$ chromium levels followed by $\gamma$ and UV irradiated B. subtilis.

GR activity significantly improved under stress, with a negligible effect of exogenous applications of strains to stressed plants. However, at $0 \mathrm{ppm}$ conditions, plants supplemented with strains (T2, T3 \& T4) showed higher GR activity compared to the plants solely supplied with nutrient medium (T1; Tables 3 and 4; Figure 3A-E).

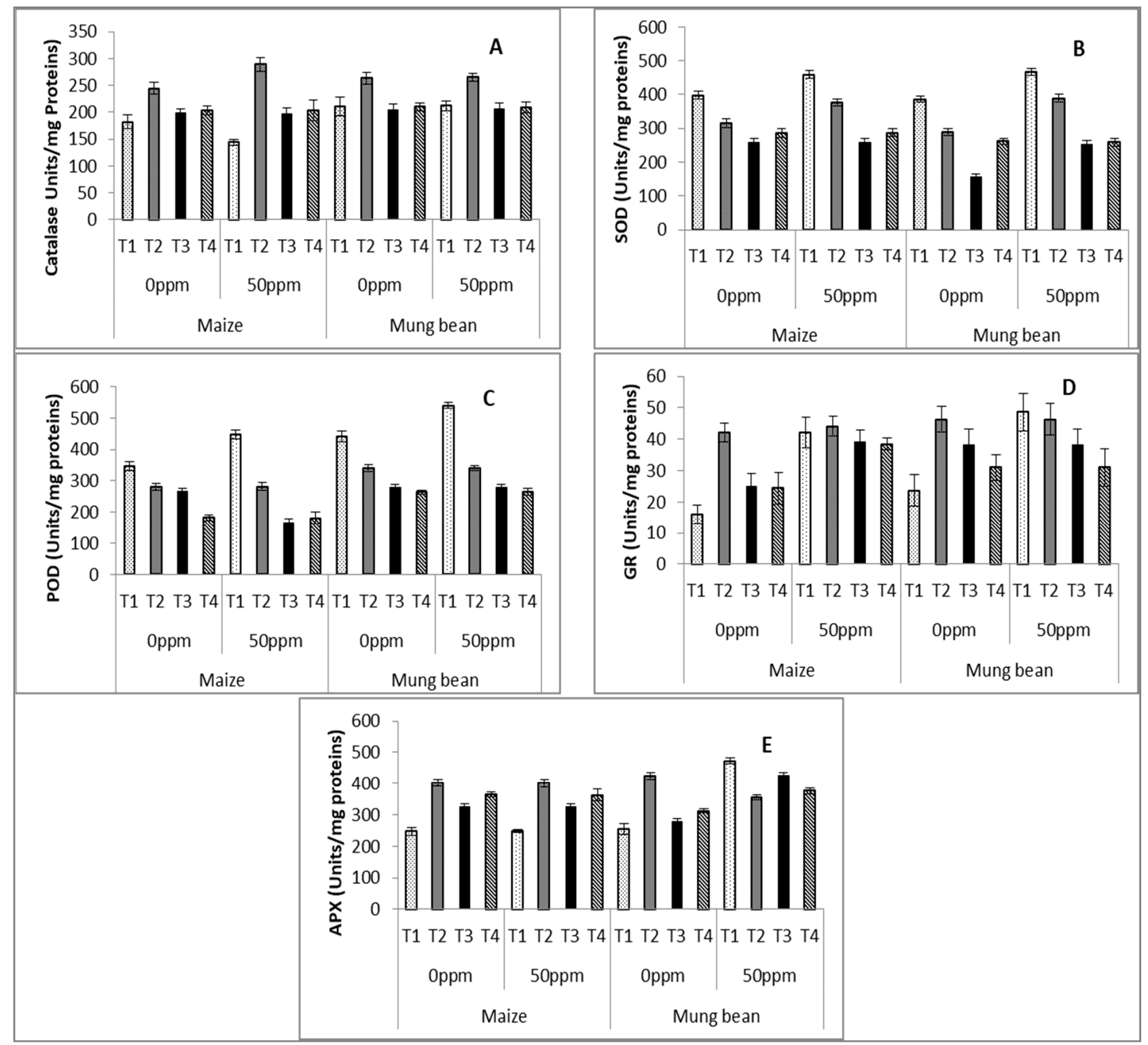

Figure 3. Estimation of activities of (A) superoxide dismutase (T1), (B) catalase (CAT), (C) peroxidase (POD), (D) glutathione reductase (GR) and (E) ascorbate oxidase (APX) enzymes of maize (Zea mays L.) and mung bean (Vigna radiata L.) exogenously treated with Bacillus subtilis under chromium stress conditions (mean \pm S.E.). Here, $\mathrm{T} 1=\mathrm{Nutrient}$ broth, $\mathrm{T} 2=\mathrm{Nutrient}$ broth + parent B. subtilis, T3 $=$ Nutrient broth + UV-irradiated B. subtilis and T4 $=$ Nutrient broth $+\gamma$-irradiated B. subtilis.

Proline concentration increased significantly $(p \leq 0.05)$ in maize upon exposure to chromium, whereas mung bean exhibited similar patterns of proline accumulation at both chromium levels. Irradiated B. subtilis (UV and $\gamma$ ) improved this attribute in both crops. 
However, the wild B. subtilis was successful in increasing proline content only in mung bean (Tables 3 and 4; Figure 4A).
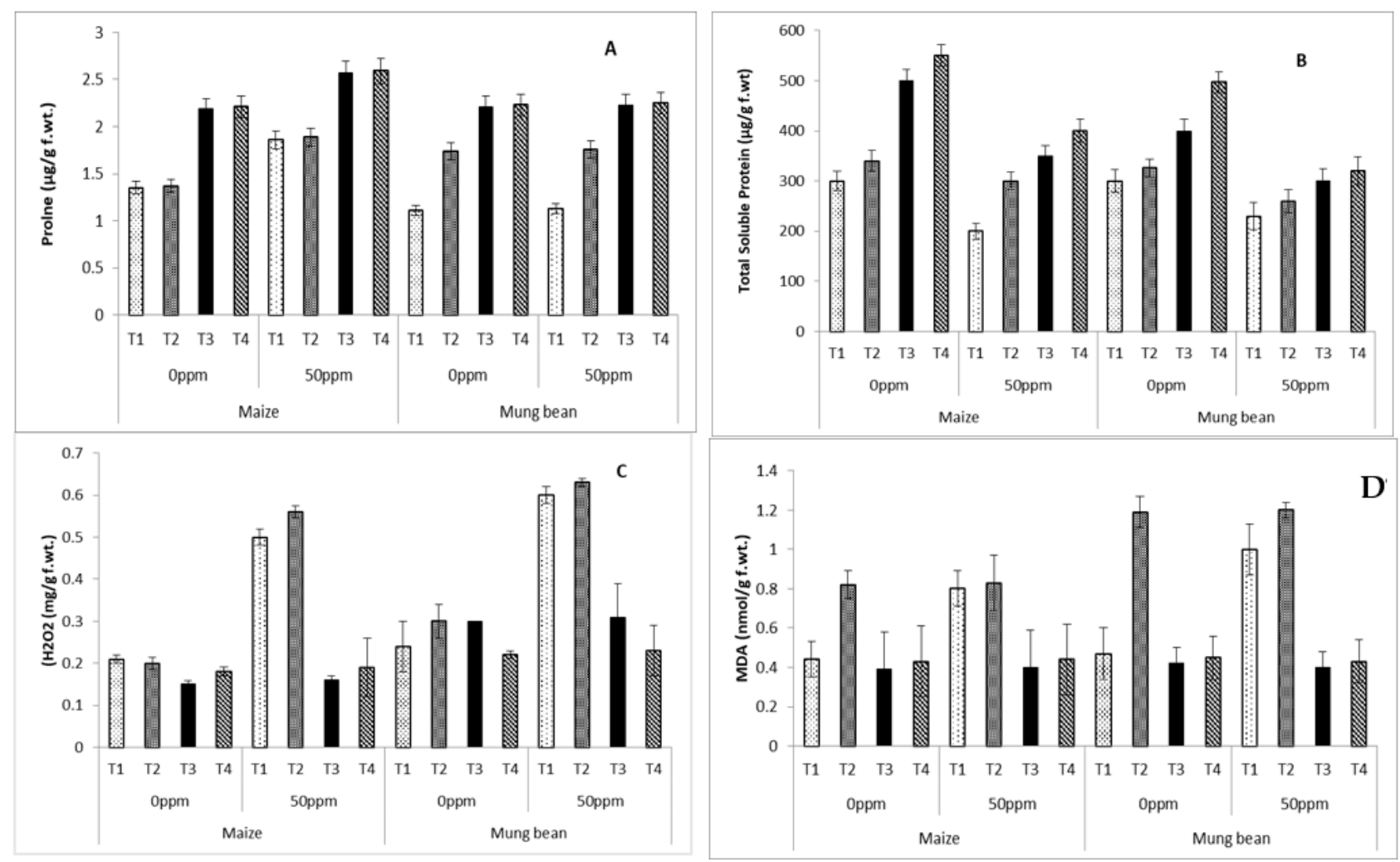

Figure 4. Biochemical attributes (A) Proline (B) Total soluble proteins (C) $\mathrm{H}_{2} \mathrm{O}_{2}$ (D) MDA of maize (Zea mays L.) and mung bean (Vigna radiata L.) exogenously treated with $B$. subtilis strains under chromium stress (0 ppm vs. 50 ppm) conditions (mean \pm S.E.). Here, $\mathrm{T} 1=$ Nutrient broth, $\mathrm{T} 2=$ Nutrient broth + parent $B$. subtilis, $\mathrm{T} 3=$ Nutrient broth $+\mathrm{UV}$-irradiated B. subtilis and $\mathrm{T} 4=$ Nutrient broth $+\gamma$-irradiated B. subtilis.

Total soluble protein was remarkably decreased under chromium stress conditions in plants lacking strains in rooting medium (T1; Tables 3 and 4; Figure 4B), whereas B subtilis supplements (Parent, UV-irradiated and $\gamma$-irradiated) significantly enhanced the accumulation of total soluble proteins in both crops (Tables 3 and 4; Figure 4B). The best total soluble protein levels were displayed by $\gamma$-irradiated strains followed by UV-irradiated and then parent $B$ subtilis (Tables 3 and 4; Figure 4B). Both crops showed marked enhancement of $\mathrm{H}_{2} \mathrm{O}_{2}$ with chromium stress in plants without any strains. Under controlled conditions, all supplemented (BS) and non-supplemented plants had similar levels of $\mathrm{H}_{2} \mathrm{O}_{2}$ (Tables 3 and 4; Figure 4C). Under chromium stress (50 ppm), exogenously applied parent $B$. subtilis remained ineffective, although UV and $\gamma$-irradiated strains were successful in decreasing its levels in both crops. Furthermore, UV-irradiated mutants performed better in maize and $\gamma$-irradiated strains performed better in mung bean. An increase was observed in the malonidialdehyde (MDA) contents of both maize and mungbean with chromium stress in plants growing without strains (T1), and with parent strains (T2) in rooting medium. UV and $\gamma$-irradiated mutation of B.subtilis were equally effective in lowering MDA content (Tables 3 and 4; Figure 4D).

Chlorophyll a decreased significantly $(p \leq 0.001)$ under chromium stress in plants supplied only with nutrient broth in rooting medium. B. subtilis strains significantly $(p \leq 0.001)$ improved chlorophyll a content under various symbiotic conditions (Parent, $\mathrm{UV}$ and $\gamma$-irradiated) in maize and mung bean. Chlorophyll $\mathrm{a}+\mathrm{b}$ experienced a marked decline with chromium application. All B. subtilis strains were successful in improving this attribute in both conditions of maize and mung bean. In both maize and mung 
bean, the ratio between chlorophyll a to $\mathrm{b}$ decreased with stress in plants grown with nutrient medium without any strain. All $B$. subtilis strains improved this ratio in both crops (Tables 2 and 3; Figure 5). Results for carotenoid content were almost negligible with regards to comparisons of means. The only significant increase was noted in parent straintreated plants in comparison to the nutrient medium-treated plants without $B$. subtilis strains (Figure 5D; Tables 2 and 3).

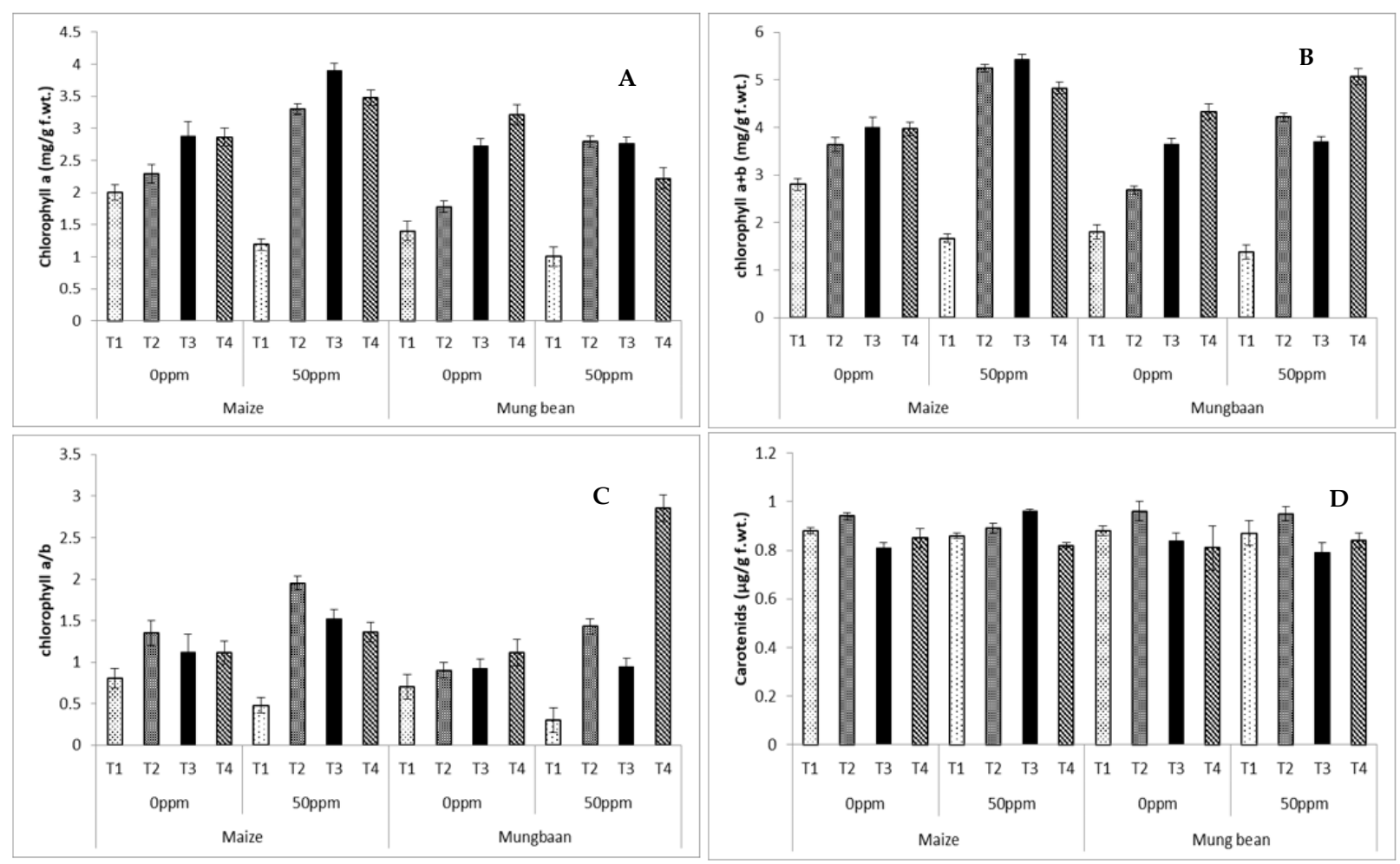

Figure 5. Photosynthetic pigments (A) chlorophyll a (B) chlorophyll $a+b(C)$ chlorophyll $a / b(D)$ carotenoids of maize (Zea mays L.) and mung bean (Vigna radiata L.) exogenously treated with different $B$. subtilis strains under chromium stress conditions (mean \pm S.E.). Here $\mathrm{T} 1=$ Nutrient broth, $\mathrm{T} 2=$ Nutrient broth + parent B. subtilis, T3 = Nutrient broth + UV-irradiated B. subtilis and T4 $=$ Nutrient broth $+\gamma$-irradiated B. subtilis.

\section{Discussion}

A substantial yield reduction in various economically important crops has been reported due to chromium stress [36]. Microbes like B. subtilis have received attention as a cheap source of bioremediation. Mutations of B. subtilis variably affected this potential of $B$. subtilis in the current project. In the present study, the best mutant strains were selected after UV and $\gamma$-irradiation treatments on the basis of their maximum potential to grow on a selective marker and their MIC values (Tables 1 and 2). Chromium stress hindered plant growth in terms of fresh and dry biomass (Tables 3 and 4; Figure 2), with significant inter-crop variation. Roots were directly exposed to chromium applied to the rooting medium; hence, both crops experienced a marked decline in biomass. Comparatively greater effects of chromium upon mung bean showed more sensitivity than maize, as it even experienced reduction of biomass in shoots. On the other hand, maize only experienced reductions in directly exposed organs (root). Maize maintained its shoot biomass under stress in plants without any strain supplement (Tables 3 and 4; Figure 2A-D). Previously, Abou-Shanab et al. [19] and Weyens et al. [20] explored the bioremediation of heavy metal stress in plants. Our findings are in line with theirs, with the additional impact of gamma and UV mutations upon strains.

In addition to osmolytes, plants may fight against abiotic stresses with the help of antioxidants, including phenolics, carotenoids, catalase, SOD, POD, APX and GR [37-39]. 
CAT has the potential to reduce stress-induced ROS [37]. Decreased antioxidative activity under heavy metal stress has been reported formerly in maize [40] and other crops [35]. In the current project, there was a limited effect of strains upon these antioxidant enzymes. Exclusively, the parent strains improved CAT activity in both C4 and C3 species. For POD activity, the rooting medium supplemented with strains even showed reduced activity in comparison to the plants grown without strains. However, activity of POD was declined by $B$. subtilis strain application in plants growing under $0 \mathrm{ppm}$ chromium. Our findings are in partial agreement with the literature [39].

Stressed plants generally attenuate oxidative stress with the help of antioxidant enzymes [41]. The currently used strains showed negligible potential for the improvement of antioxidant enzymes in both species used.

Plants growing under heavy metal stress may also be able to cope using the synthesis/accumulation of some osmoprotectants [29,41-43]. These osmolytes help in the maintenance of cell turgor and osmo-regulation of stressed plants [42,43]. One of the most commonly reported osmoprotectants is leaf free proline. In a number of crops including sweet basil [44], rice [45] and many other crops [46], proline accumulation has been correlated with stress tolerance. In the present study, maize showed an enhanced accumulation of proline under chromium stress $(0 \mathrm{ppm})$ in the absence of strains. This indicated better chromium tolerance in comparison to mung bean, which was also displayed in terms of growth attributes-particularly shoot and root weights (fresh and dry). These findings are in line with the reports of Anjum et al. [41]; they also observed better accumulation of osmolytes in maize plants growing with chromium stress. Strains of B. subtilis improved the proline content in both species, where mutants showing better accumulation of proline supported our hypothesis. Both species showed a similar reduction of total soluble proteins in plants without strains. Strain supplementation improved protein content, where the maximum was obtained by $\gamma$-irradiated $B$. subtilis, followed by UV and then parent strains.

High oxidative stressors like chromium are believed to enhance $\mathrm{H}_{2} \mathrm{O}_{2}$ generation [47].

Shah et al., in their recent work [48], applied a B. subtilis strain to induce lead stress tolerance in Solanum melongena. There was a limited decline in $\mathrm{H}_{2} \mathrm{O}_{2}$ and MDA when the parent strain was applied alone, whereas enhanced reduction was noted when the strain was synergistically applied with silicon in stressed plants. In the current study, the responses of mutated strains were similar. However, the parent strains failed to decrease these stress indicators; the parent strains increased the levels of $\mathrm{H}_{2} \mathrm{O}_{2}$ and MDA. Greater $\mathrm{H}_{2} \mathrm{O}_{2}$ and MDA contents are indicative of higher lipid peroxidation. Hence, increases in these attributes in stressed plants grown with exclusive nutrient broth (T1) or with broth and parent strain (T1) combined supported the concept of irradiation for strain improvement (Tables 3 and 4; Figure 4A,B). In contrast to our results, there are some reports where exogenously applied Bacillus subtilis has played a significant role in lowering $\mathrm{H}_{2} \mathrm{O}_{2}$ as well as MDA content [49]

It is well known that chromium stress can considerably decrease photosynthetic pigment levels, which results in reduced plant growth and yield $[45,46]$. Chromium stress also leads to the reduction of the synthesis of green pigments (chlorophyll contents), resulting in decreased rates of photosynthesis [46]. In the present study, both crops exhibited a decline in chlorophyll $\mathrm{a}$, chlorophyll $\mathrm{a}+\mathrm{b}$ and chlorophyll $\mathrm{a} / \mathrm{b}$ under stress in the absence of any $B$. subtilis strain (Figure 5C; Table 1). These findings are in agreement with Anjum et al. [41]. Reductions in chlorophyll may be due to the enhanced activities of chlorophyllase, involved in the breakdown of chlorophyll under stress conditions [49]. Several studies have reported the decrease of chlorophylls and carotenoids by chromium stress [7,42]. The chlorophyll $\mathrm{a} / \mathrm{b}$ ratio is an important parameter indicative of plant metabolic efficiency; it is actually related to the phothosystem II (PSII) core and light-harvesting complex II (LHCII) ratio. PSII cores perceive excited energy from LHCII. Therefore, this chlorophyll $\mathrm{a} / \mathrm{b}$ ratio indicates the activity of the plant photosynthetic machinery [50]. In the present study, B. subtilis strains proved themselves beneficial in the alleviation of chromium stress, with the improvement of photosynthetic pigments in addition to improved plant growth. 
Currently, the decline in the chlorophyll $\mathrm{a} / \mathrm{b}$ ratio in chromium-stressed plants growing without strains and the treatment-based increases in this ratio supported our hypothesis. With minor variations, all strains improved photosynthetic activity (Figure 5).

\section{Conclusions}

In the absence of $B$. subtilis strains, maize shows comparatively better chromium tolerance in comparison to mung bean (in terms of root and shoot fresh weight, and root and shoot lengths, proline levels, and MDA and GR activity).

All strains of B. subtilis (parent, $\gamma$ - irradiated and UV- irradiated) proved their positive role in the growth and metabolism of maize and mung bean grown under chromium stresswell shown by the enhancement of proline, total soluble protein, chlorophyll $a, a+b$ and $\mathrm{a} / \mathrm{b}$ levels. The irradiated strains $(\gamma$-and UV) further maintained their superiority over the parent strains, with better reductions in lipid peroxidation markers $\left(\mathrm{H}_{2} \mathrm{O}_{2}\right.$ and MDA).

Overall, $\gamma$ and UV-irradiated B. subtilis showed comparable results; therefore, either can be applied based upon technical availability. In future, similar strains may be applied to obtain metabolomics-level data for plants.

Author Contributions: Conceptualization, S.M. and S.J.; methodology, S.M. and S.J.; software, S.M. and S.J.; validation, T.M. and S.J.; formal analysis, Q.S.; investigation, Q.S.; resources, S.J. and T.M.; data curation, S.J.; writing—original draft preparation, S.J.; writing—review and editing, S.J. and S.M.; supervision, S.J.; project administration, S.J.; Funding Acquisition, S.J. All authors have read and agreed to the published version of the manuscript.

Funding: GCUF-RSP (11-ACH-11).

Acknowledgments: Authors are thankful to Ayyub Agriculture Research Faisalabad, Pakistan for providing the seeds of maize (Mallika) and mung bean (PRI-2018) varieties.

Conflicts of Interest: There is no conflict of interest.

Sample Availability: All strains, plant materials and chemicals are available from the authors.

\section{References}

1. Wang, J.; Chen, C. Biosorbents for heavy metals removal and their future. Biotechnol. Adv. 2009, 27, 195-226. [CrossRef]

2. Wang, R.; Gao, F.; Guo, B.-Q.; Huang, J.-C.; Wang, L.; Zhou, Y.-J. Short-term chromium-stress-induced alterations in the maize leaf proteome. Int. J. Mol. Sci. 2013, 14, 11125-11144. [CrossRef] [PubMed]

3. Farid, M.; Shakoor, M.B.; Ehsan, S.; Ali, S.; Zubair, M.; Hanif, M. Morphological, physiological and biochemical responses of different plant species to Cd stress. Int. J. Chem. Biochem. Sci. 2013, 3, 53-60.

4. Dey, S.; Mukhopadhyay, T.; Naskar, S.; Dey, T.; Chalak, H.; Adhikari, S. Probabilistic characterisation for dynamics and stability of laminated soft core sandwich plates. J. Sandw. Struct. Mater. 2019, 21, 366-397. [CrossRef]

5. Ranieri, E.; Gikas, P. Effects of plants for reduction and removal of hexavalent chromium from a contaminated soil. Water Air Soil Pollut. 2014, 225, 1981. [CrossRef]

6. Babula, P.; Adam, V.; Opatrilova, R.; Zehnalek, J.; Havel, L.; Kizek, R. Uncommon heavy metals, metalloids and their plant toxicity: A review. In Organic Farming, Pest Control and Remediation of Soil Pollutant; Springer: Cham, Switzerland, 2009; pp. 275-317.

7. Rodriguez, E.; Santos, C.; Azevedo, R.; Moutinho-Pereira, J.; Correia, C.; Dias, M.C. Chromium (VI) induces toxicity at different photosynthetic levels in pea. Plant Physiol. Biochem. 2012, 53, 94-100. [CrossRef] [PubMed]

8. Dixit, V.; Pandey, V.; Shyam, R. Chromium ions inactivate electron transport and enhance superoxide generation in vivo in pea (Pisum sativum L. cv. Azad) root mitochondria. Plant Cell Environ. 2002, 25, 687-693. [CrossRef]

9. Choudhury, S.; Panda, S.K. Toxic effects, oxidative stress and ultrastructural changes in moss Taxithelium nepalense (Schwaegr.) Broth. under chromium and lead phytotoxicity. Water Air Soil Pollut. 2005, 167, 73-90. [CrossRef]

10. Brunetti, G.; Farrag, K.; Rovira, P.S.; Nigro, F.; Senesi, N. Greenhouse and field studies on $\mathrm{Cr}, \mathrm{Cu}, \mathrm{Pb}$ and $\mathrm{Zn}$ phytoextraction by Brassica napus from contaminated soils in the Apulia region, Southern Italy. Geoderma 2011, 160, 517-523. [CrossRef]

11. Adrees, M.; Ali, S.; Rizwan, M.; Zia-ur-Rehman, M.; Ibrahim, M.; Abbas, F.; Farid, M.; Qayyum, M.F.; Irshad, M.K. Mechanisms of silicon-mediated alleviation of heavy metal toxicity in plants: A review. Ecotoxicol. Environ. Saf. 2015, 119, 186-197. [CrossRef]

12. Fahad, S.; Hussain, S.; Matloob, A.; Khan, F.A.; Khaliq, A.; Saud, S.; Hassan, S.; Shan, D.; Khan, F.; Ullah, N. Phytohormones and plant responses to salinity stress: A review. Plant Growth Regul. 2015, 75, 391-404. [CrossRef]

13. Ashraf, A.; Sarfraz, R.A.; Mahmood, A.; ud Din, M. Chemical composition and in vitro antioxidant and antitumor activities of Eucalyptus camaldulensis Dehn. leaves. Ind. Crop. Prod. 2015, 74, 241-248. [CrossRef] 
14. Shi, J.; Fu, X.-Z.; Peng, T.; Huang, X.-S.; Fan, Q.-J.; Liu, J.-H. Spermine pretreatment confers dehydration tolerance of citrus in vitro plants via modulation of antioxidative capacity and stomatal response. Tree Physiol. 2010, 30, 914-922. [CrossRef] [PubMed]

15. Farhangi-Abriz, S.; Ghassemi-Golezani, K. How can salicylic acid and jasmonic acid mitigate salt toxicity in soybean plants? Ecotoxicol. Environ. Saf. 2018, 147, 1010-1016. [CrossRef] [PubMed]

16. Rajkumar, M.; Freitas, H. Effects of inoculation of plant-growth promoting bacteria on Ni uptake by Indian mustard. Bioresour. Technol. 2008, 99, 3491-3498. [CrossRef] [PubMed]

17. Luo, S.; Xu, T.; Chen, L.; Chen, J.; Rao, C.; Xiao, X.; Wan, Y.; Zeng, G.; Long, F.; Liu, C. Endophyte-assisted promotion of biomass production and metal-uptake of energy crop sweet sorghum by plant-growth-promoting endophyte Bacillus sp. SLS18. Appl. Microbiol. Biotechnol. 2012, 93, 1745-1753. [CrossRef]

18. Idris, R.; Trifonova, R.; Puschenreiter, M.; Wenzel, W.W.; Sessitsch, A. Bacterial communities associated with flowering plants of the Ni hyperaccumulator Thlaspi goesingense. Appl. Environ. Microbiol. 2004, 70, 2667-2677. [CrossRef] [PubMed]

19. Abou-Shanab, R.; Angle, J.; Chaney, R. Bacterial inoculants affecting nickel uptake by Alyssum murale from low, moderate and high Ni soils. Soil Biol. Biochem. 2006, 38, 2882-2889. [CrossRef]

20. Weyens, N.; Van der Lelie, D.; Taghavi, S.; Newman, L.; Vangronsveld, J. Exploiting plant-microbe partnerships to improve biomass production and remediation. Trends Biotechnol. 2009, 27, 591-598. [CrossRef]

21. Glick, B.R. Plant Growth-Promoting Bacteria: Mechanisms and Applications. Scientifica 2012, 2012, 963401. [CrossRef]

22. Ward, J.K.; Tissue, D.T.; Thomas, R.B.; Strain, B.R. Comparative responses of model C3 and C4 plants to drought in low and elevated $\mathrm{CO}_{2}$. Glob. Chang. Biol. 1999, 5, 857-867. [CrossRef]

23. Nayyar, H.; Gupta, D. Differential sensitivity of C3 and C4 plants to water deficit stress: Association with oxidative stress and antioxidants. Environ. Exp. Bot. 2006, 58, 106-113. [CrossRef]

24. Sheng, X.-F.; Xia, J.-J.; Jiang, C.-Y.; He, L.-Y.; Qian, M. Characterization of heavy metal-resistant endophytic bacteria from rape (Brassica napus) roots and their potential in promoting the growth and lead accumulation of rape. Environ. Pollut. 2008, 156, 1164-1170. [CrossRef] [PubMed]

25. Wuana, R.; Okieimen, F. Phytoremediation potential of maize (Zea mays L.). A review. Afr. J. Gen. Agric. $2010,6,275-287$.

26. Javed, S.; Meraj, M.; Bukhari, S.A.; Irfan, R.; Mahmood, S. Hyper-production of alkaline protease by mutagenic treatment of Bacillus subtilis M-9 using agroindustrial wastes in submerged fermentation. J. Microb. Biochem. Technol. 2013, 5, 74-80.

27. Cakmak, I.; Horst, W.J. Effect of aluminium on lipid peroxidation, superoxide dismutase, catalase, and peroxidase activities in root tips of soybean (Glycine max). Physiol. Plant. 1991, 83, 463-468. [CrossRef]

28. Wang, S.Y.; Jiao, H.J.; Faust, M. Changes in ascorbate, glutathione, and related enzyme activities during thidiazuron-induced bud break of apple. Physiol. Plant. 1991, 82, 231-236. [CrossRef]

29. Ghanti, K.; Rao, S.; Venugopal, R.; Rao, S.; Kaviraj, C.; Barad, A. Somatic embryogenesis and Agrobacterium-mediated transformation in chickpea (Cicer arietinum L.). Plant Cell Biotechnol. Mol. Biol. 2002, 3, 51-58.

30. Donahue, J.L.; Okpodu, C.M.; Cramer, C.L.; Grabau, E.A.; Alscher, R.G. Responses of antioxidants to paraquat in pea leaves (relationships to resistance). Plant Physiol. 1997, 113, 249-257. [CrossRef]

31. Velikova, V.; Yordanov, I.; Edreva, A. Oxidative stress and some antioxidant systems in acid rain-treated bean plants. Protective role of exogenous polyamines. Plant Sci. 2000, 151, 59-66. [CrossRef]

32. Bates, L.S.; Waldren, R.P.; Teare, I.D. Rapid determination of free proline for water-stress studies. Plant Soil 1973, $39,205-207$. [CrossRef]

33. Peterson, G.L. A simplification of the protein assay method of Lowry et al. which is more generally applicable. Anal. Biochem. 1977, 83, 346-356. [CrossRef]

34. Palta, J.P. Leaf chlorophyll content. Remote Sens. Rev. 1990, 5, 207-213. [CrossRef]

35. Davis, D.; Gross, E. Protein-protein interactions of the light-harvesting chlorophyll ab protein. II. Evidence for two stages of cation independent association. Biochim. Biophys. Acta (BBA) Bioenerg. 1976, 449, 554-564. [CrossRef]

36. Javed, S.; Yasin Ashraf, M.; Meraj, M.; Anwer Bukhari, S.; Zovia, I. Salinity and drought induced antioxidant responses in different cultivars of safflower (Carthamus tinctorius L.). Curr. Pharm. Biotechnol. 2013, 14, 814-819. [CrossRef]

37. Prazeres, C.S.; Coelho, C.M. Osmolyte accumulation and antioxidant metabolism during germination of vigorous maize seeds subjected to water deficit. Acta Sci. Agron. 2020, 42, e42476. [CrossRef]

38. Mahmood, S.; Afzal, B.; Perveen, S.; Wahid, A.; Azeem, M.; Iqbal, N. He-Ne Laser Seed Treatment Improves the Nutraceutical Metabolic Pool of Sunflowers and Provides Better Tolerance against Water Deficit. Front. Plant Sci. 2021, 17, 804.

39. Farooq, A.; Bukhari, S.A.; Akram, N.A.; Ashraf, M.; Wijaya, L.; Alyemeni, M.N.; Ahmad, P. Exogenously applied ascorbic acid-mediated changes in osmoprotection and oxidative defense system enhanced water stress tolerance in different cultivars of safflower (Carthamus tinctorious L.). Plants 2020, 9, 104. [CrossRef]

40. Reddy, C.A.; Saravanan, R.S. Polymicrobial multi-functional approach for enhancement of crop productivity. In Advances in Applied Microbiology; Elsevier: Amsterdam, The Netherlands, 2013; Volume 82, pp. 53-113.

41. Anjum, S.A.; Ashraf, U.; Imran, K.; Tanveer, M.; Shahid, M.; Shakoor, A.; Longchang, W. Phyto-toxicity of chromium in maize: Oxidative damage, osmolyte accumulation, anti-oxidative defense and chromium uptake. Pedosphere 2017, 27, 262-273. [CrossRef]

42. Ganesh, K.S.; Baskaran, L.; Rajasekaran, S.; Sumathi, K.; Chidambaram, A.; Sundaramoorthy, P. Chromium stress induced alterations in biochemical and enzyme metabolism in aquatic and terrestrial plants. Colloids Surf. B Biointerfaces 2008, 63, 159-163. [CrossRef] 
43. Ovando-Martinez, M.; Sáyago-Ayerdi, S.; Agama-Acevedo, E.; Goñi, I.; Bello-Pérez, L.A. Unripe banana flour as an ingredient to increase the undigestible carbohydrates of pasta. Food Chem. 2009, 113, 121-126. [CrossRef]

44. Moradi, F.; Ismail, A.M. Responses of photosynthesis, chlorophyll fluorescence and ROS-scavenging systems to salt stress during seedling and reproductive stages in rice. Ann. Bot. 2007, 99, 1161-1173. [CrossRef] [PubMed]

45. Çiçek, N.; Çakirlar, H. The effect of salinity on some physiological parameters in two maize cultivars. Bulg. J. Plant Physiol. 2002, 28, 66-74.

46. Singh, V.; Praveen, V.; Khan, F.; Tripathi, C.K.M. Phylogenetics of an antibiotic producing Streptomyces strain isolated from soil. Bioinformation 2009, 4, 5334. [CrossRef]

47. Augustine, A.; Onwuka, J.; Albert, C. Determination of heavy metal concentration in Neem (Azadirachta indica) leaves, bark and soil along some major roads in Lafia, Nasarawa State Nigeria. J. Environ. Chem. Ecotoxicol. 2016, 8, 38-43.

48. Shah, A.A.; Yasin, N.A.; Akram, K.; Ahmad, A.; Khan, W.U.; Akram, W.; Akbar, M. Ameliorative role of Bacillus subtilis FBL-10 and silicon against lead induced stress in Solanum melongena. Plant Physiol. Biochem. 2021, 158, 486-496. [CrossRef]

49. Parida, B.; Chhibba, I.; Nayyar, V. Influence of nickel-contaminated soils on fenugreek (Trigonella corniculata L.) growth and mineral composition. Sci. Hortic. 2003, 98, 113-119. [CrossRef]

50. Souza, L.R.R.; Bernardes, L.E.; Barbetta, M.F.S.; Da Veiga, M.A.M.S. Iron oxide nanoparticle phytotoxicity to the aquatic plant Lemna minor: Effect on reactive oxygen species (ROS) production and chlorophyll a/chlorophyll b ratio. Environ. Sci. Pollut. Res. 2019, 26, 24121-24131. [CrossRef] [PubMed] 